\title{
Real-time polymerase chain reaction optimised for hepatitis $C$ virus detection in dried blood spots from HIV-exposed infants, KwaZulu-Natal, South Africa
}

\begin{tabular}{|c|c|}
\hline \multicolumn{2}{|c|}{$\begin{array}{l}\text { Authors: } \\
\text { Anneta Naidoo }{ }^{1,2} \\
\text { Raveen Parboosing } \\
\text { Pravi Moodley }\end{array}$} \\
\hline \multicolumn{2}{|c|}{$\begin{array}{l}\text { Affiliations: } \\
\text { Department of Virology, } \\
\text { Nelson R Mandela School of } \\
\text { Medicine, School of } \\
\text { Laboratory Medicine and } \\
\text { Medical Sciences, University } \\
\text { of KwaZulu-Natal, Durban, } \\
\text { KwaZulu-Natal, South Africa }\end{array}$} \\
\hline \multicolumn{2}{|c|}{$\begin{array}{l}{ }^{2} \text { National Health Laboratory } \\
\text { Services, Inkosi Albert Luthuli } \\
\text { Central Hospital, Durban, } \\
\text { KwaZulu-Natal, South Africa }\end{array}$} \\
\hline \multicolumn{2}{|c|}{$\begin{array}{l}\text { Corresponding author and } \\
\text { email: } \\
\text { Anneta Naidoo } \\
\text { anneta.naidoo@gmail.com }\end{array}$} \\
\hline \multicolumn{2}{|c|}{$\begin{array}{l}\text { Dates: } \\
\text { Received: } 30 \text { Sept. } 2014 \\
\text { Accepted: } 08 \text { Jan. } 2016 \\
\text { Published: } 18 \text { Mar. } 2016\end{array}$} \\
\hline \multicolumn{2}{|c|}{$\begin{array}{l}\text { How to cite this article: } \\
\text { Naidoo A, Parboosing R, } \\
\text { Moodley P. Real-time } \\
\text { polymerase chain reaction } \\
\text { optimised for hepatitis C } \\
\text { virus detection in dried blood } \\
\text { spots from HIV-exposed } \\
\text { infants, KwaZulu-Natal, } \\
\text { South Africa. Afr J Lab Med. } \\
\text { 2016;5(1), Art. \#269, } 6 \text { pages. } \\
\text { http://dx.doi.org/10.4102/ } \\
\text { ajlm.v5i1.269 }\end{array}$} \\
\hline \multicolumn{2}{|c|}{$\begin{array}{l}\text { Copyright: } \\
\text { C 2016. The Authors. } \\
\text { Licensee: AOSIS. This work } \\
\text { licensed under the Creative } \\
\text { Commons Attribution } \\
\text { License. }\end{array}$} \\
\hline \multicolumn{2}{|l|}{ Read online: } \\
\hline 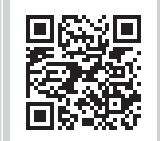 & $\begin{array}{l}\text { Scan this QR } \\
\text { code with your } \\
\text { smart phone or } \\
\text { mobile device } \\
\text { to read online. }\end{array}$ \\
\hline
\end{tabular}

Background: There is a paucity of data on the prevalence of hepatitis $\mathrm{C}$ virus (HCV) in children, particularly in sub-Saharan Africa. A major obstacle in resource-limited settings for polymerase chain reaction (PCR) testing is the necessity for specimen transportation and storage at low temperatures. There are numerous recent studies of using real-time HCV PCR for diagnosis and screening of plasma and serum, but few have looked at using dried blood spot (DBS) specimens.

Objectives: The aim of this study was to optimise a real-time HCV PCR method to detect HCV RNA from infant DBS specimens for use as a tool for HCV surveillance in KwaZulu-Natal, South Africa.

Method: The LightCycler® 2.0 instrument was used for the HCV PCR using the LightCycler® RNA Master SYBR Green I kit. Template volume, primer concentration and primer annealing temperatures were optimised and the method was used on 179 DBS specimens from HIV-exposed infants in KwaZulu-Natal.

Results: Primer concentrations adjusted to $0.25 \mu \mathrm{M}$ and a template volume of $10 \mu \mathrm{L}$ improved the PCR amplification. Primer annealing temperatures lowered from $65^{\circ} \mathrm{C}$ to $58^{\circ} \mathrm{C}$ resulted in higher quantities of amplified PCR product. The limit of detection of the optimised HCV PCR assay was between $1200 \mathrm{IU} / \mathrm{mL}$ and $3580 \mathrm{IU} / \mathrm{mL}$ of HCV RNA. HCV was not detected in any of the 179 DBS specimens.

Conclusion: The optimised real-time HCV PCR on infant DBS specimens performed well, but HCV was not found in this surveillance study. HIV infection may have little impact on the vertical transmission of $\mathrm{HCV}$ in this region.

\section{Introduction}

Hepatitis $\mathrm{C}$ virus (HCV) infects 3\% of the global population, ${ }^{1}$ but there is a paucity of data on HCV prevalence in children, particularly children in sub-Saharan Africa. ${ }^{2}$ HCV is usually transmitted to infants vertically, with a rate that varies from $3 \%$ to $7 \%$, although it may increase two- to five-fold with HIV co-infection. ${ }^{3}$ The prevalence of HCV is higher amongst HIV-positive patients because of shared routes of transmission and common risk factors. ${ }^{4}$ The estimated prevalence of HCV in sub-Saharan Africa was 3\% amongst HIV-negative individuals in 2002, but prevalence increased to $7 \%$ amongst individuals with HIV co-infection by $2014 .{ }^{5}$ The prevalence of HCV / HIV co-infection in South Africa was $0.1 \%$ in $2002^{6}$ compared to $3.5 \%$ amongst individuals infected only with HCV. ${ }^{7}$ There are reasons to suspect that the prevalence of HCV may be high in KwaZulu-Natal, South Africa. Firstly, KwaZulu-Natal has a high antenatal HIV prevalence of $40.1 \%{ }^{8}$ Secondly, KwaZulu-Natal has a high overall adult HCV prevalence of $6.4 \%$ and a much higher prevalence of $\mathrm{HCV} / \mathrm{HIV}$ co-infection $(13.4 \%),{ }^{9}$ which may imply a high prevalence of $\mathrm{HCV}$ amongst pregnant woman. The World Health Organization suggests that screening for HCV in regions with a high prevalence of HIV should be conducted, but depends on $\mathrm{HCV}$ prevalence and resources. ${ }^{10}$

In a region with a high prevalence of both HIV and HCV, especially amongst pregnant women, ${ }^{9}$ it is important to determine the prevalence of $\mathrm{HCV}$ amongst infants. Although most children with chronic $\mathrm{HCV}$ infection remain asymptomatic, some may have mild abnormalities in liver function and chronic HCV infection may progress to severe liver disease, end-stage liver disease and death. ${ }^{2}$ Liver disease resulting from HCV infection is a major cause of mortality and morbidity amongst adults co-infected with HIV and HCV, which further compounds the hepatotoxic effects of antiretroviral therapy. ${ }^{4}$ 
Infant diagnosis of HCV by molecular-based technologies is superior to serological techniques for detecting $\mathrm{HCV}$ infection by means of maternal antibodies circulating in infants. ${ }^{2} \mathrm{~A}$ major obstacle in resource-limited settings for polymerase chain reaction (PCR) testing is the necessity of transporting and storing specimens at low temperatures. However, using dried blood spot (DBS) specimens, which do not require refrigeration, significantly reduces pre-analytical problems and is widely used in molecular virology for the detection of viral nucleic acids. ${ }^{11}$

Numerous studies have reported on the use of real-time PCR for HCV diagnosis using plasma and serum, ${ }^{12,13,14,15,16,17,18,19,20}$ although few have looked at DBS specimens. ${ }^{21,22,23,24,25}$ However, a few recent studies have found good correlations for adult serum and plasma compared with DBS specimens analysed using commercial HCV PCR assays. 26,27,28,29

The prevalence of HCV amongst HIV-exposed infants in KwaZulu-Natal, South Africa is unknown. Therefore, the aim of this study was to optimise a real-time PCR assay to detect HCV RNA from HIV-exposed infant DBS specimens for use as a tool for HCV surveillance in KwaZulu-Natal, South Africa.

\section{Research method and design Ethical considerations}

Ethical clearance was obtained from the University of KwaZulu-Natal Biomedical Research Ethics Committee (BE273/090). Informed consent was not required since this was a retrospective study in which we used discarded specimens from routine testing. All data were recorded and then anonymised for the purposes of the study. Specifically, HIV PCR results, HCV PCR results, age and clinical diagnosis were recorded anonymously in a spreadsheet. No patient identifiers were recorded.

\section{Study design}

This study was conducted retrospectively in the laboratory at the Department of Virology, National Health Laboratory Service/University of KwaZulu-Natal, at the Inkosi Albert Luthuli Central Hospital in Durban, South Africa. This is a reference laboratory which receives all DBS specimens from public sector facilities in KwaZulu-Natal for PCR testing of DNA from HIV-exposed infants for early diagnosis of HIV infection. The number of DBS specimens tested by the laboratory has steadily increased each year from 13699 in 2005 to 73033 in 2012. The uptake of HIV PCR testing amongst HIV-exposed infants in KwaZulu-Natal has also increased from $18 \%$ in 2005 to $97.4 \%$ in $2011 . .^{30}$ A sample size of 179 was calculated using Epi-Info ${ }^{\mathrm{TM}} 6$ (Centre for Disease Control, Atlanta, Georgia, United States, 1998) using the number of live births in KwaZulu-Natal, ${ }^{30}$ the prevalence of HIV amongst antenatal attendees (which approximates the percentage of HIV-exposed infants) ${ }^{8}$ and the approximate $\mathrm{HCV}$ seropositivity in infants, based on data from the laboratory information system. The sample size was representative of
HIV-exposed infants who attended public health facilities in KwaZulu-Natal and who required HIV PCR testing because of suspected HIV exposure or clinical suspicion of HIV infection.

\section{Specimen collection}

As part of routine early infant diagnosis of HIV, infants' blood is collected by heel-prick and spotted onto Whatman Filter paper in four circles. In the laboratory, two spots are cut out and used for routine HIV PCR testing within four to five days of DBS specimen collection. After releasing the results, the card (with the two unused spots) is routinely stored at room temperature for at least three months and then discarded. These discarded DBS specimens were tested for $\mathrm{HCV}$ after specimens had been stored for at least three months after initial collection. Specimens with inadequate volume (where the entire circle was not filled with blood) were excluded from the study. Acceptable DBS specimens were sequentially selected from August to December 2010 until 179 specimens were obtained. External quality control specimens were purchased from Quality Control for Molecular Diagnostics (QCMD; Glasgow, Scotland) and internal quality control specimens were prepared in-house.

\section{Laboratory methods}

Before automated extraction, using the NucliSENS ${ }^{8}$ easyMag ${ }^{\circledR}$ Extraction (biomérieux, Marcy I'Etoile, France), two DBS (approximately $50 \mu \mathrm{L}$ blood per spot) were cut with sterilised scissors into a $1.5 \mathrm{~mL}$ eppendorf tube and $2 \mathrm{~mL}$ NucliSENS ${ }^{\circledR}$ easyMAG ${ }^{\circledR}$ lysis buffer containing $5 \mathrm{M}$ guanidinium thiocyanate was added to the tube. The lysis buffer was also added to the quality control specimens. The specimens were agitated for 30 minutes on an orbital shaker and centrifuged at $1500 \times \mathrm{g}$ for two minutes. Supernatant was pipetted into transfer wells, which were then loaded onto the automated extraction system. Briefly, cell-bound nucleic acids were released with the chaotropic agent - guanidinium thiocyanate - and then bound to silica particles, which were immobilised on a filter. Impurities were removed by several washes in buffers containing guanidinium thiocyanate, $70 \%$ ethanol and acetone, after which the purified nucleic acids were eluted in molecular grade water.

The LightCycler ${ }^{\circledR} 2.0$ instrument (Roche Diagnostics, Mannheim, Germany) was used to perform reverse transcription and amplification in a one-step assay using the LightCycler ${ }^{\circledR}$ RNA Master SYBR Green I kit (Roche Diagnostics, Mannheim, Germany), which contained the enzymes Thermus thermophilus DNA polymerase, dNTPs, reaction buffer and SYBR Green I fluorescent dye.

The primers used in the reverse transcription PCR were KY80 (sense) 5'-GCA GAA AGC GTC TAG CCA TGG CGT-3' and KY78 (antisense) 5'-CTC GCA AGC ACC CTA TCA GGC AGT-3'. These primers target the highly-conserved 5'-noncoding region of the $\mathrm{HCV}$ genome to produce a PCR product of $244 \mathrm{bp}$ and are known to detect all HCV genotypes. ${ }^{31}$ The reverse transcription PCR master mix 
consisted of PCR-grade water, $\mathrm{Mn}(\mathrm{OAc})_{2}$, both primers and the LightCycler® RNA Master SYBR Green I mix.

The reverse transcription and PCR parameters were set according to the LightCycler ${ }^{\circledR}$ RNA Master SYBR Green I package insert. Reverse transcription of the template RNA was performed at $61^{\circ} \mathrm{C}$ for 20 minutes. Complementary DNA (cDNA) was amplified over 40 cycles of denaturation, annealing and extension. Denaturation and extension were performed at the temperatures on the package insert. The annealing temperature was calculated using the melting temperatures of the primers, namely, $65^{\circ} \mathrm{C}\left(4^{\circ} \mathrm{C}\right.$ subtracted from $\left.69^{\circ} \mathrm{C}\right)$, using standard PCR optimisation guidelines, whereby a range of annealing temperatures $\left(55^{\circ} \mathrm{C}\right.$ to $65^{\circ} \mathrm{C}$ ) was used to determine the optimal annealing temperature, where efficiency of PCR amplification was maximal..$^{32}$ Melting curve analysis to identify PCR products was performed as described on the package insert. The PCR products were detected with a SYBR Green I dye, which intercalates with double-stranded DNA and is detected at a wavelength of $530 \mathrm{~nm}$.

Primer concentrations and template volumes were optimised using the methods described on the LightCycler ${ }^{\circledR}$ RNA Master SYBR Green I package insert. Primer concentrations ranging from $0.1 \mu \mathrm{M}$ to $0.5 \mu \mathrm{M}$, using two-fold dilutions, were used to determine the optimal primer concentration capable of detecting the lowest concentration of $\mathrm{HCV}$ RNA. Template volumes of $1 \mu \mathrm{L}, 5 \mu \mathrm{L}$ and $10 \mu \mathrm{L}$ were used to determine the optimal starting concentration of the template RNA.

The HCV Quantitative PCR proficiency panel (QCMD, Glasgow, Scotland) was prepared in five-fold dilutions as an external quality control standard to calculate the lower limit of detection of the optimised HCV RNA PCR assay.

For the preparation of the in-house internal quality control specimens, HCV-negative whole blood was provided by the South African National Blood Services (Durban, South Africa). These DBS specimens were prepared by spiking the HCV-negative whole blood with $\mathrm{HCV}$-positive plasma (3 $580000 \mathrm{IU} / \mathrm{mL}$ ) obtained from the National Institute of Communicable Diseases (Sandringham, Johannesburg, South Africa). This plasma was tested for $\mathrm{HCV}$ using the COBAS AmpliPrep/COBAS TaqMan Hepatitis C Virus assay on the COBAS AmpliPrep and COBAS TaqMan 48 analyser (Roche Diagnostics, Mannheim, Germany). Ten-fold serial dilutions were made, with a starting concentration of $3580000 \mathrm{IU} / \mathrm{mL}$ of HCV RNA, resulting in values of $3580000 \mathrm{IU} / \mathrm{mL}$, $358000 \mathrm{IU} / \mathrm{mL}, 35800 \mathrm{IU} / \mathrm{mL}$ and $3580 \mathrm{IU} / \mathrm{mL}$. Unspiked whole blood was used as a negative control. Fifty microliters $(50 \mu \mathrm{L})$ of the positive and negative internal control specimens were spotted onto Whatman Filter paper to mimic infant DBS specimens.

\section{Results}

Primer concentrations adjusted to $0.25 \mu \mathrm{M}$ and a template volume of $10 \mu \mathrm{L}$ improved PCR amplification. An annealing temperature of $58{ }^{\circ} \mathrm{C}$ resulted in higher levels of amplified PCR product compared with an annealing temperature of $65{ }^{\circ} \mathrm{C}$. Quality control specimens with HCV RNA values of $<10000 \mathrm{IU} / \mathrm{mL}$ were detectable at an annealing temperature of $58{ }^{\circ} \mathrm{C}$. Detection at a melting temperature of $86{ }^{\circ} \mathrm{C}$ was indicative of an $\mathrm{HCV}$-positive result (Figure 1) for quality control specimens with viral loads of $13646 \mathrm{IU} / \mathrm{mL}$ (high), $7063 \mathrm{IU} / \mathrm{mL}$ (medium) and $3972 \mathrm{IU} / \mathrm{mL}$ (low). The external quality control specimens with known HCV viral loads of $30000 \mathrm{IU} / \mathrm{mL}, 6000 \mathrm{IU} / \mathrm{mL}$ and $1200 \mathrm{IU} / \mathrm{mL}$ were detected by the PCR, whereas external quality control specimens with an $\mathrm{HCV}$ viral load of $240 \mathrm{IU} / \mathrm{mL}$ were undetectable (Figure 2). The in-house HCV quality control specimens with viral loads of $3580000 \mathrm{IU} / \mathrm{mL}, 358000 \mathrm{IU} / \mathrm{mL}, 35800 \mathrm{IU} / \mathrm{mL}$ and $3580 \mathrm{IU} / \mathrm{mL}$ were all detected by the HCV PCR (Figure 3 ).

The lowest concentration detected by the optimised HCV PCR was $1200 \mathrm{IU} / \mathrm{mL}$ (Figure 2) when using the QCMD quality control specimens. The in-house internal quality control DBS specimens were detected with viral loads as low as $3580 \mathrm{IU} / \mathrm{mL}$ of HCV RNA (Figure 3).

Of the 179 infant DBS specimens, 13 tested HIV-positive and 166 tested HIV-negative via PCR. All 179 DBS specimens tested negative for HCV using the optimised real-time PCR assay.

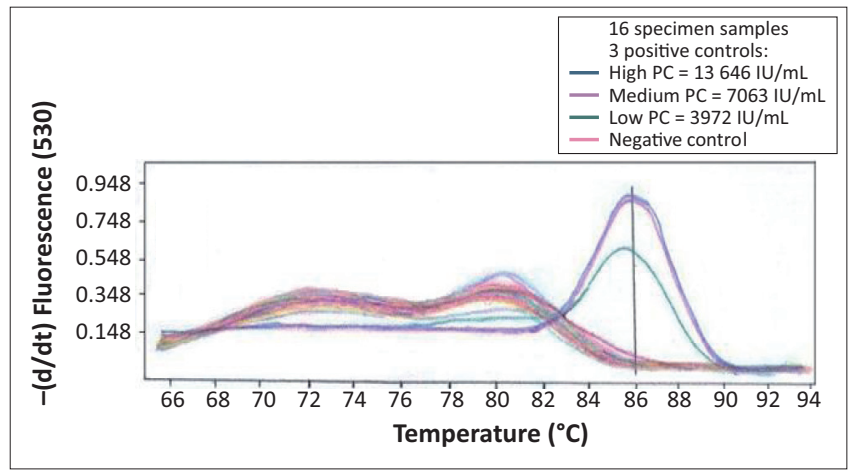

$\mathrm{HCV}$, hepatitis $\mathrm{C}$ virus; $\mathrm{PC}$, positive control.

FIGURE 1: Melting curves at a melting temperature of $86{ }^{\circ} \mathrm{C}$ represent $\mathrm{HCV}$-positive controls. Sixteen specimens that tested negative for HCV by serology were used as HCV-negative controls.

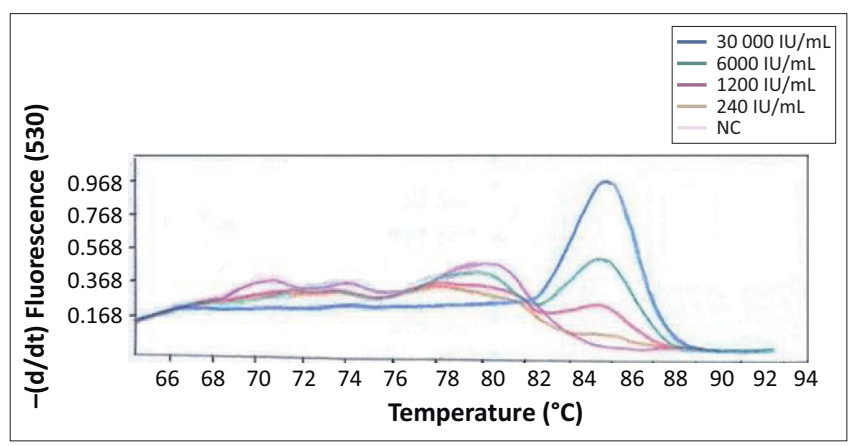

$\mathrm{HCV}$, hepatitis C virus; RNA, ribonucleic acid; PCR, polymerase chain reaction; NC, negative control.

FIGURE 2: External quality controls. The melting curves show results of five-fold dilutions of HCV-positive external quality control specimens. These specimens were used to determine the lowest HCV RNA-positive concentrations that the optimised PCR assay could detect. HCV RNA at concentrations of $30000 \mathrm{IU} / \mathrm{mL}$, $6000 \mathrm{IU} / \mathrm{mL}$ and $1200 \mathrm{IU} / \mathrm{mL}$ were detected by the assay, whereas concentrations of $240 \mathrm{IU} / \mathrm{mL}$ of HCV RNA and lower were undetectable. 


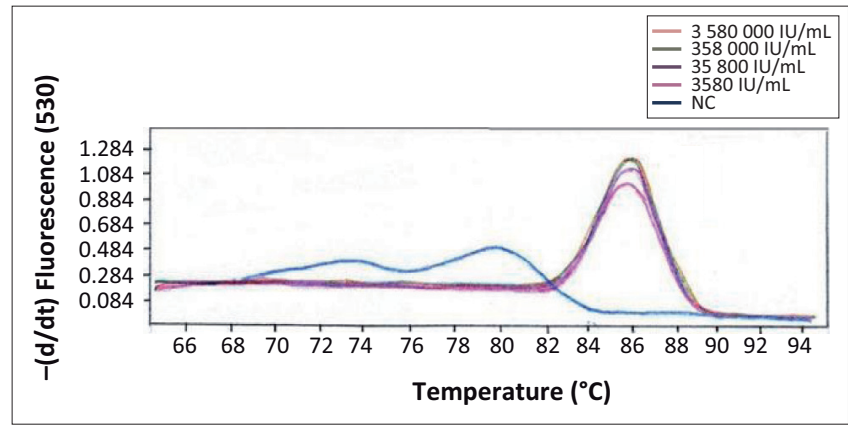

DBS, dried blood spot; HCV, hepatitis C virus; RNA, ribonucleic acid; PCR, polymerase chain reaction; NC, negative control.

FIGURE 3: Internal quality controls. Internal quality control DBS specimens were prepared by spiking HCV-negative whole blood with HCV-positive plasma. Ten-fold dilutions were prepared with a starting concentration of $3580000 \mathrm{IU} / \mathrm{mL}$ of HCV RNA and added onto Whatman Filter paper. HCV negative whole blood was used as a negative control. An HCV RNA concentration of $3580 \mathrm{IU} / \mathrm{mL}$ was the lowest concentration of RNA detected for DBS using the optimised PCR assay.

\section{Discussion}

We optimised a real-time PCR test for HCV using DBS specimens from infants as a simple method for qualitative $\mathrm{HCV}$ detection. Although our method was qualitative, it was able to detect at least $3580 \mathrm{IU} / \mathrm{mL}$ and $1200 \mathrm{IU} / \mathrm{mL}$ in various types of quality control specimens. This could be useful for detecting acute $\mathrm{HCV}$ infections, which generally have viral loads less than $10^{5} \mathrm{IU} / \mathrm{mL}{ }^{33}$ The detection of amplified nucleic acid using SYBR Green I is inexpensive and is an easier technical approach in comparison to other real-time PCR formats such as TaqMan and molecular beacon detection methods. ${ }^{14}$ It is possible that HCV RNA viral load in our infant DBS specimens was below the level of detection of the assay, since HCV RNA viral loads amongst infants in the first year of infection may be too low for detection. ${ }^{3}$

DBS specimens have improved the cost-effectiveness, coverage and availability of molecular-based testing in resource-limited settings..$^{11,24,34,35}$ This has resulted in the development of several optimised PCR techniques to detect HCV using DBS. ${ }^{21,22,24,25}$ As with our method, several of these techniques are based on real-time PCR and, like De Crignis, ${ }^{22}$ we used LightCycler® technology with SYBR Green I as the fluorophore..$^{21,24,25}$ Probe-based detection methods are known to improve the sensitivity of target detection, but increase the cost of the testing. ${ }^{21}$ The limit of detection varies amongst assays. Our assay had a limit of detection of $3580 \mathrm{IU} / \mathrm{mL}$, which is higher than previously reported limits of detection of $2500 \mathrm{IU} / \mathrm{mL}^{22}$ and $250 \mathrm{IU} / \mathrm{mL}^{21}$ This difference may be attributed to differences in storage conditions of the DBS specimens before testing and differences in methods of RNA extraction, which may result in variations in the number of copies of starting RNA. ${ }^{11,25,34}$ Additionally, DBS specimen volumes are lower when compared with plasma and serum specimens, which reduces the amount of RNA extracted. ${ }^{34}$ Thus, the correlation between HCV viral load from DBS and $\mathrm{HCV}$ viral load from plasma or serum may be imprecise, suggesting that DBS specimens are better suited to diagnosis, whereas plasma or serum are better suited to monitoring of HCV antiviral treatment. ${ }^{34}$ These methods for HCV testing using real-time PCR have been applied to $\mathrm{HCV}$ treatment monitoring, ${ }^{24}$ screening for $\mathrm{HIV} / \mathrm{HCV}$ co-infection ${ }^{22}$ and surveillance for HCV amongst intravenous drug users. ${ }^{36}$ Our real-time HCV PCR was used on DBS specimens from an infant population, which may be useful for HCV surveillance amongst infants.

The use of DBS specimens for HCV PCR has several advantages. ${ }^{11,34,35}$ Firstly, they are easier to collect than whole blood and present a lower infectious hazard. Secondly, specimen transportation and storage are cheaper, since refrigeration is not required. Lastly, the long-term stability of nucleic acids in DBS has been proven for molecular analysis. Therefore, real-time HCV PCR using DBS specimens for HCV surveillance has been used to understand the molecular epidemiology of HCV. . $^{21,22,23,24,25,36}$

\section{Limitations}

Our HCV PCR optimisation has several limitations. Firstly, the results are not representative of all infants, since only specimens from HIV-exposed infants who require an HIV PCR were tested. Secondly, our optimised HCV PCR may not be optimal for routine clinical diagnostic purposes, although it may be convenient for surveillance work. Thirdly, we did not compare our DBS specimen method to those using whole blood. However, we did use alternative methods to evaluate our PCR assay, which included testing external quality control specimens with known $\mathrm{HCV}$ viral loads ranging from $1081 \mathrm{IU} / \mathrm{mL}$ to $34594 \mathrm{IU} / \mathrm{mL}$ and clinical HCV-positive and $\mathrm{HCV}$-negative specimens from a reference laboratory. Further, positive and negative controls were included in each run. Lastly, we chose not to follow previously described methods but to optimise our own method, because it was more cost-effective than other real-time techniques reported. In addition, we used existing equipment and in-house PCR consumables that the technical staff in our laboratory were already proficient in using.

Given that our DBS specimens were from HIV-exposed infants in KwaZulu-Natal, we expected to find a moderate prevalence of HCV amongst these infants as reported by other African countries with populations co-infected with $\mathrm{HIV}$ and HCV. ${ }^{37,38,39}$ Infection with HIV is a risk factor for $\mathrm{HCV}$ transmission in co-infected pregnant women and is known to increase vertical transmission. ${ }^{3,4}$ The fact that we did not detect HCV RNA in our study specimens may be because of the prolonged storage ( $\geq 3$ months) of our DBS specimens at room temperature, which may have resulted in degradation of HCV RNA. ${ }^{25}$

Furthermore, perinatal transmission of HCV requires a high maternal HCV viral load. ${ }^{3}$ Detection of HCV RNA at birth is usually indicative of intrauterine infection, whereas infection during delivery is associated with HCV RNA being detected only after infants are aged six months; in addition, delivery by caesarean section is less frequently associated with $\mathrm{HCV}$ transmission than vaginal delivery. ${ }^{3}$ However, clinical information, such as maternal HCV viral load, mode of 
delivery of infants, infant liver function markers, risk factors (such as HBV co-infection) and laboratory results (such as CD4 cell counts and HIV viral loads) were not available for our study.

\section{Conclusion}

We have demonstrated that using an optimised real-time HCV PCR assay on DBS specimens from HIV-exposed infants is a good technique for HCV detection and may be well suited for surveillance purposes in resource-limited settings. To our knowledge, this is the first surveillance in South Africa using an optimised real-time HCV PCR to report the prevalence of $\mathrm{HCV}$ amongst HIV-exposed infants. Considering that HCV was not detected in our DBS specimens, HCV prevalence in this population of infants in KwaZulu-Natal, South Africa may be low and may have little impact on HIV-exposed infants. Therefore, further surveillance for HCV amongst HIV-exposed infants in our setting may not be necessary. However, HCV surveillance may still be prudent for HIVexposed infants in countries with moderate to high HIV and $\mathrm{HCV}$ prevalence and should include collection of clinical information and data about confounding factors.

\section{Acknowledgements Competing interests}

The authors declare that they have no financial or personal relationship(s) which may have inappropriately influenced them in writing this article.

\section{Sources of support}

We would like to thank the National Institute of Communicable Diseases, Gauteng for providing us with serum samples positive for HCV. We also appreciate the South African National Blood Services, Durban providing us with HCV-negative blood.

\section{Authors' contributions}

R.P. (University of KwaZulu-Natal/National Health Laboratory Services) designed the project and analysed the data. A.N. (University of KwaZulu-Natal/National Health Laboratory Services) performed the laboratory work and was responsible for writing the manuscript. P.M. (University of KwaZuluNatal/National Health Laboratory Services) assisted in writing and preparing the article

\section{References}

1. Lavanchy D. Evolving epidemiology of hepatitis $C$ virus. Clin Microbiol Infect. 2011;17(2):107-115. http://dx.doi.org/10.1111/j.1469-0691.2010.03432.x

2. Nel E, Sokol RJ, Comparcola D, et al. Viral hepatitis in children. J Paediatr Gastroenterol Nutr. 2012;55(5):500-505. http://dx.doi.org/10.1097/MPG.0b013e318272aee7

3. Yeung $C-Y$, Lee $H-C$, Chan $W-T$, et al. Vertical transmission of hepatitis $C$ virus: current knowledge and perspectives. World J Hepatol. 2014;6(9):643-651. http:// dx.doi.org/10.4254/wjh.v6.i9.643

4. Operskalski EA, Kovacs A. HIV/HCV co-infection: pathogenesis, clinical complications, treatment, and new therapeutic technologies. Curr HIV/AIDS Rep. 2011;8(1):12-22. http://dx.doi.org/10.1007/s11904-010-0071-3

5. Barth RE, Huijgen Q, Taljaard J, et al. Hepatitis B/C and HIV in sub-Saharan Africa: an association between highly prevalent infectious diseases. A systematic review and meta-analysis. Int J Infect Dis. 2010;14(12):e1024-e1031. http://dx.doi. org/10.1016/j.ijid.2010.06.013

6. Hoffmann CJ, Dayal D, Cheyip M, et al. Prevalence and associations with hepatitis $B$ and hepatitis C infection among HIV-infected adults in South Africa. Int J STD AIDS. 2012;23(10):e10-e13. http://dx.doi.org/10.1258/ijsa.2009.009340

7. Madhava V, Burgess C, Drucker E. Epidemiology of chronic hepatitis C virus infection in sub-Saharan Africa. Lancet Infect Dis. 2002;2(5):293-302. http:// dx.doi.org/10.1016/S1473-3099(02)00264-5

8. National Department of Health. The 2013 national antenatal sentinel HIV prevalence survey, South Africa. Pretoria: National Department of Health; 2013.

9. Parboosing R, Paruk I, Lalloo UG. Hepatitis C virus seropositivity in a South African cohort of HIV co-infected, ARV naïve patients is associated with renal insufficiency and increased mortality. J Med Virol. 2008;80(9):1530-1536. http://dx.doi.org/ 10.1002/jmv.21262

10. World Health Organization. Guidelines for the screening, care and treatment of persons with hepatitis C infection. Geneva: World Health Organization; 2014.

11. Smit PW, Elliott I, Peeling RW, et al. An overview of the clinical use of filter paper in the diagnosis of tropical diseases. Am J Trop Med Hyg. 2014;90(2):195-210. http://dx.doi.org/10.4269/ajtmh.13-0463

12. Albertoni G, Castelo Girão M, Schor N. Mini review: Current molecular methods for the detection and quantification of hepatitis B virus, hepatitis C virus, and human immunodeficiency virus type 1. Int J Infect Dis. 2014;25:145-149. http:// dx.doi.org/10.1016/j.ijid.2014.04.007

13. Chevaliez S, Bouvier-Alias M, Rodriguez C, et al. The Cobas AmpliPrep/Cobas TaqMan HCV Test, Version 2.0, real-time PCR assay accurately quantifies hepatitis C virus genotype 4 RNA. J Clin Microbiol. 2013;51(4):1078-1082. http://dx.doi. org/10.1128/JCM.02004-12

14. Laughlin TS, Nuccie B, Rothberg PG. Genotyping of hepatitis $C$ virus by sequence analysis of the amplicon from the Roche Cobas AmpliPrep/Cobas TaqMan viral load assay. J Clin Microbiol. 2010;48(2):671-672. http://dx.doi.org/10.1128/JCM. 01519-09

15. Mousavi-Fard SH, Merat S, Shahzamani K, et al. Development of a SYBR green real time multiplex RT-PCR technique for simultaneous detection of HCV and GBV-C co-infection in plasma samples. MBD. 2014;1(1):41-49.

16. Paryan M, Forouzandeh MM, Kia V, et al. Design and development of an in-house multiplex RT-PCR assay for simultaneous detection of HIV-1 and HCV in plasma samples. Iran J Microbiol. 2012;4(1):8-14.

17. Rozales FD, de-Paris F, Machado ABMP, et al. Optimization of one-step real-time PCR for the X-tail target of HCV as a diagnostic test. Clin Biomed Res. 2014; 34(2):164-168.

18. Shahzamani K, Sabahi F, Merat $S$, et al. Rapid low-cost detection of hepatitis $C$ virus RNA in HCV-infected patients by real-time RT-PCR using SYBR Green I. Arch Iran Med. 2011;14(6):396-400.

19. Zhang EZ, Bartels DJ, Frantz JD, et al. Development of a sensitive RT-PCR method for amplifying and sequencing near full-length HCV genotype 1 RNA from patient samples. Virol J. 2013:10:53. http://dx.doi.org/10.1186/1743-422X-10-53

20. Zaghloul MHE, Rizk EM, Elsayed AR, et al. Detection of HCV-RNA by real time PCR using SYBRGREEN DYE I. Int J Adv Res. 2015;3(6):1450-1458.

21. Bennett $S$, Gunson RN, McAllister GE, et al. Detection of hepatitis $C$ virus RNA in dried blood spots. J Clin Virol. 2012;54(2):106-109. http://dx.doi.org/10.1016/j. jcv.2012.02.004

22. De Crignis E, Re MC, Cimatti L, et al. HIV and HCV detection in DBS by SYBR green multiplex real time RT-PCR. J Virol Methods. 2010;165(1):51-56. http://dx.doi org/10.1016/j.jviromet.2009.12.017

23. Hope VD, Hickman M, Ngui SL, et al. Measuring the incidence, prevalence and genetic relatedness of hepatitis $C$ infections among a community recruited sample of injecting drug users, using dried blood spots. J Viral Hepat. 2011;18(4):262-270. http://dx.doi.org/10.1111/j.1365-2893.2010.01297.x

24. Santos C, Reis A, dos Santos CV, et al. The use of real-time PCR to detect hepatitis $C$ virus RNA in dried blood spots from Brazilian patients infected chronically. J Virol Methods. 2011;179(1):17-20. http://dx.doi.org/10.1016/j.jviromet.2011.06.012

25. Tuaillon $E$, Mondain A, Meroueh F, et al. Dried blood spot for Hepatitis $C$ virus serology and molecular testing. Hepatology. 2010;51(3):752-758.

26. Soulier A, Poiteau L, Rosa I, et al. Dried blood spots: a tool to ensure broad access to hepatitis C screening, diagnosis, and treatment monitoring. J Infect Dis. 2015 Sep 2. pii:jiv423. Epub ahead of print. http://dx.doi.org/10.1093/infdis/jiv423

27. Mutagi A, Atherton C, Wilson S, et al. Development of qualitative HCV RNA testing on dried blood spots as an adjunct screening tool to identify active hepatitis C infection. Open Forum Infect Dis. 2014:1(suppl 1):S376-S377.

28. Fouad NA, Mahedy AW, El-taher SM. Application of dried blood spot testing for hepatitis C virus RNA amplification. Egypt J Med Microbiol. 2013;22(11):1-8. $\mathrm{http}: / / \mathrm{dx}$.doi.org/10.12816/0004921

29. Ross RS, Stambouli O, Grüner N, et al. Detection of infections with hepatitis B virus, hepatitis $C$ virus, and human immunodeficiency virus by analyses of dried blood spots - performance characteristics of the ARCHITECT system and two commercial assays for nucleic acid amplification. Virol J. 2013;10:72. http://dx doi.org/10.1186/1743-422X-10-72

30. Moodley P, Parboosing R, Moodley D. Reduction in perinatal HIV infections in KwaZulu-Natal, South Africa, in the era of more effective prevention of mother to child transmission interventions (2004-2012). J Acquir Immune Defic Syndr. 2013;63(3):410-415. http://dx.doi.org/10.1097/QAl.0b013e3182926931

31. Young KY, Resnick RM, Myers TW. Detection of hepatitis C virus RNA by a combined reverse transcription-polymerase chain reaction assay. J Clin Micro. 1993;31(4): 882-886. 
32. Rapley R, Whitehouse D, editors. Molecular biology and biotechnology. 6th ed. Cambridge, United Kingdom: Royal Society of Chemistry; 2014.

33. McGovern BH, Birch CE, Bowen MJ, et al. Improving the diagnosis of acute hepatitis C virus infection with expanded viral load criteria. Clin Infect Dis. 2009;49(7):1051-1060. http://dx.doi.org/10.1086/605561

34. Greenman J, Roberts T, Cohn J, et al. Dried blood spot in the genotyping quantification and storage of HCV RNA: a systematic literature review. J Vira Hepat. 2015;22(4):353-361. http://dx.doi.org/10.1111/jvh.12345

35. Snijdewind IJM, van Kampen JJA, Fraaij PLA, et al. Current and future applications of dried blood spots in viral disease management. Antiviral Res. 2012;93(3) 309-321. http://dx.doi.org/10.1016/j.antiviral.2011.12.011

36. Hickman $M$, McDonald $T$, Judd $A$, et al. Increasing the uptake of hepatitis $C$ virus testing among injecting drug users in specialist drug treatment and prison settings by using dried blood spots for diagnostic testing: a cluster randomized control trial. J Viral Hepat. 2008;15(4):250-254. http://dx.doi.org/10.1111/j.1365-2893. 2007.00937.x

37. Njouom R, Pasquier C, Ayouba A, et al. Low risk of mother-to-child-transmission of hepatitis C virus in Yaounde, Cameroon: the ANRS 1262 study. Am J Trop Med Hyg. 2005;73(2):460-466.

38. Ogboghodo BC, Aigbirior MA, Bazuaye $\mathrm{GN}$, et al. Hepatitis $C$ virus and human immunodeficiency virus-I (HIV) co-infection in children in Benin City, Nigeria. Afr. J. Biomed. Res. 2009;12(1):1-6.

39. Sadoh AE, Sadoh WE, Iduoriyekemwen NJ. HIV co-infection with hepatitis B and C viruses among Nigerian children in an antiretroviral treatment programme. S. Afr. J. Child Health. 2011;5(1):7-10. 